\title{
Effect of Metal (Cu, Mn) Doping on the Structural, Morphological, Optical, Photoluminescence, Electrical and Photocatalytic Properties of In2s3 Nanoparticles
}

\author{
A. Kennedy ( $\sim$ kennedycsice@gmail.com ) \\ CSI College of Engineering \\ H. Ganesan \\ Sri Ranganathar Institute of engineering and Technology \\ T. Govindaraj \\ Sri Ramakrishna Mission Vidyalaya College of Arts and Science

\section{J. Maalmargan} \\ Sri Ranganathar Institute of engineering and Technology \\ K. Bagyalakshmi \\ Sri Ranganathar Institute of engineering and Technology
}

\section{Research Article}

Keywords: In2S3 nanoparticles, Co-precipitation, Structural properties, Optical properties, Photocatalytic properties

Posted Date: June 10th, 2021

DOl: https://doi.org/10.21203/rs.3.rs-588347/v1

License: (c) (i) This work is licensed under a Creative Commons Attribution 4.0 International License.

Read Full License 
Effect of metal (Cu, Mn) doping on the Structural, morphological, optical, photoluminescence, electrical and photocatalytic properties of $\operatorname{In}_{2} \mathrm{~S}_{3}$ nanoparticles

\author{
A. Kennedy ${ }^{1}$, H. Ganesan ${ }^{2}$, T. Govindaraj ${ }^{3}$, J.Maalmargan $^{4}$, K.Bagyalakshmi ${ }^{4}$, \\ ${ }^{1}$ Department of Physics, CSI College of Engineering, Ooty - 643 215, Tamilnadu, India. \\ ${ }^{2}$ Department of Mechanical Engineering, Sri Ranganathar Institute of engineering and
}

Technology, Coimbatore 641020, Tamilnadu, India.

${ }^{3}$ Nanotechnology Laboratory, Department of Physics, Sri Ramakrishna Mission Vidyalaya College of Arts and Science, Coimbatore 641020, Tamilnadu, India.

${ }^{4}$ Department of Electrical and Electronics Engineering, Sri Ranganathar Institute of engineering and Technology, Coimbatore 641020, Tamilnadu, India.

\title{
*Corresponding author (e-mail: kennedycsice@ gmail.com)
}

\section{A B S T R A C T}

Pure and metal $(\mathrm{Cu}, \mathrm{Mn})$ doped $\operatorname{In}_{2} \mathrm{~S}_{3}$ nanoparticles were prepared by the standard co-precipitation technique. This work aims to study the influence of metal $(\mathrm{Cu}, \mathrm{Mn})$ on the synthesized nanoparticles' structural, morphological, optical, photoluminescence, and electrical properties (NPs). The XRD pattern reveals that the metal $(\mathrm{Cu}, \mathrm{Mn})$ doped $\mathrm{In}_{2} \mathrm{~S}_{3}$ NPs were polycrystalline with a cubic phase whose particle size varies between 36.2 and 49 nm. A significant decrease in the crystallite size was observed after metal doping. It is noted from the EDS spectra the elements like $\mathrm{In}, \mathrm{Cu}, \mathrm{Mn}$ and $\mathrm{S}$ are present in the NPs. The optical studies reveal that the high transmittance $(80 \%)$ was observed for pure $\operatorname{In}_{2} \mathrm{~S}_{3}$ NPs makes them an efficient window layer for solar cell applications. Also, the calculated bandgap energy was found to increase $(2.8-3.28$ e V) for metal doping. Photoluminescence measurements reveal that the photoemission is mainly due to the donor-acceptor pair transitions. The electrical studies indicate that the electrical conductivity decreases significantly with doping, and maximum electrical conductivity of $1.28 \times 10^{-6}(\Omega \mathrm{m})^{-1}$ was obtained for pure $\operatorname{In}_{2} \mathrm{~S}_{3}$ NPs. A photocatalytic study reveals that high photocatalytic activity is observed for Mn-doped NPs under Methylene blue (84\%). 
Keywords: $\operatorname{In}_{2} \mathrm{~S}_{3}$ nanoparticles, Co-precipitation, Structural properties, Optical properties, Photocatalytic properties.

\section{Introduction}

As our civilization is more technologically advanced, the demand for every aspect of our life is grown drastically. The fabrication of nanomaterials and their applications in every area of our human life is thriving. Nanomaterials exhibit naval, chemical, electrical, mechanical and magnetic properties different from their bulk counterparts [1-2]. Nanoscale $\left(10^{-9} \mathrm{~m}\right)$ materials have a large surface to volume ratio compared to their bulk, accelerating nanomaterials' work as absorbents and catalysts [3]. Further, sensors and sensing technology play an essential role in information gathering [4]. Recently, mixing nanopowders with fuels have enhanced engine performance [5]. In technological application, $\operatorname{In}_{2} \mathrm{~S}_{3}$ is an important semiconducting material because of its photoconductive behaviour, wide bandgap, and stability [6-7]. Since $\operatorname{In}_{2} \mathrm{~S}_{3}$ is nontoxic and has bandgap energy (2.0 e V) more significant than Cds, improving the light transmission in the Visible-IR regions can be used as an adequate and suitable substitute for Cds in the making of solar cell devices [8-10].

Copper indium disulfide $\left(\mathrm{CuInS}_{2}\right)$ is an essential ternary semiconducting material. It has a direct bandgap value of 1.5 - 3.16 e V, which closely matches the solar spectrum. Further, $\mathrm{CuInS}_{2}$ shows excellent photo-irradiation stability and has a high absorption coefficient [10]. Therefore, $\mathrm{CuInS}_{2}$ was investigated as the material of choice for thin-film photovoltaics [11].

Manganese indium sulphide $\left(\mathrm{MnIn}_{2} \mathrm{~S}_{4}\right)$ is the most promising magnetic material of the I-III-VI semiconductor family with bandgap energy 1.95-3.28 e V depending on its composition and deposition technique [12-13]. $\mathrm{MnIn}_{2} \mathrm{~S}_{4}$ exhibits excellent optical transmittance (75\%) and high optical absorption coefficient $\left(>10^{5} \mathrm{~cm}^{-1}\right)$. These excellent physical properties of $\mathrm{MnIn}_{2} \mathrm{~S}_{4}$ finds wide application in functional devices such as switches, optical filters, photodetectors, light modulators and other devices like optoelectronic and Schottky diodes [14-15].

In general, doping is a practical approach to improve the physical properties of nanopowders [16]. In the present work, pure and metal-doped $(\mathrm{Cu}, \mathrm{Mn}) \mathrm{In}_{2} \mathrm{~S}_{3} \mathrm{NPs}$ are prepared by the standard co-precipitation method. Several methods like sol-gel processing [17], hydrothermal [18], co-precipitation [19], chemical vapour deposition [20] and microemulsion [21] are used to synthesize pure and metal-doped $\operatorname{In}_{2} \mathrm{~S}_{3} \mathrm{NPs}$ effectively. The co- 
precipitation method is an effective method widely used to prepare pure and metal-doped NPs at room temperature on a large scale with affordable cost [22-23].

Herein, We prepared $\mathrm{Cu}$ and $\mathrm{Mn}$-doped $\operatorname{In}_{2} \mathrm{~S}_{3}$ nanoparticles by the simple co-precipitation method for Optoelectronic and photocatalytic applications. The effect of dopants on prepared catalysts have been investigated by structural, morphological, optical, electrical and photocatalytic properties. As outcomes, The high transmittance and low resistivity of $\mathrm{Mn}^{2+}$ doped the nano samples convenient for optoelectronic applications.

\section{Materials and methods}

\subsection{Material deposition}

Analytical grade chemicals such as Indium chloride $\left(\mathrm{InCl}_{3}\right)$ and thiourea $\mathrm{CS}\left(\mathrm{NH}_{2}\right)_{2}$ are used to prepare $\mathrm{In}_{2} \mathrm{~S}_{3}$ NPs. The appropriate quantity of $\mathrm{InCl}_{3}$ and $\mathrm{CS}\left(\mathrm{NH}_{2}\right)_{2}$ are mixed thoroughly in a beaker with de-ionized water in the molar ratio of 1:1. The stock solution of sodium hydroxide $(\mathrm{NaOH})$ is added drop by drop using a burette to this solution. The final solution is kept under constant magnetic stirring until precipitation is formed. After the formation of evident precipitation, the beaker is sealed and undisturbed for 6 hours. Then the precipitation is dried in an oven at $40^{\circ} \mathrm{C}$ for 4 hours. The final product is crushed by using an agate motor to obtain pure $\operatorname{In}_{2} S_{3}$ nanoparticles.

A similar method is implemented for the preparation of $\mathrm{Cu}$ doped $\mathrm{In}_{2} \mathrm{~S}_{3}$ nanoparticles. For the preparation of $\mathrm{Cu}$ : $\mathrm{In}_{2} \mathrm{~S}_{3} \mathrm{NPs}$, the Copper chloride $\left(\mathrm{CuCl}_{2}\right)$ is added to the mixture of $\mathrm{InCl}_{3}$ and $\mathrm{CS}\left(\mathrm{NH}_{2}\right)_{2}$ in the molar ratio of 0.2:0.1:0.7. Further, the Mn-doped $\mathrm{In}_{2} \mathrm{~S}_{3} \mathrm{NPs}$ are prepared by adding the $\mathrm{MnCl}_{2}$ to the combined Indium chloride and thiourea product under constant magnetic stirring.

\subsection{Characterization techniques}

The phase identification and crystallite sizes were determined by the X-ray diffraction (XRD) in the range of $10-80^{\circ}$ with $\mathrm{CuK} \alpha$ radiation source $(\lambda=1.5406 \AA)$. The surface morphology of pure and metal-doped $(\mathrm{Cu}, \mathrm{Mn})$ and the grain size distribution of $\mathrm{Cu}$ and $\mathrm{Mn}$-doped $\operatorname{In}_{2} \mathrm{~S}_{3}$ NPs were investigated using FE-SEM operated at $30 \mathrm{KV}$ with a scanning rate of $50 \mu$ s. The elemental composition analysis of the synthesized samples was carried out using energy-dispersive X-ray spectroscopy (EDS - model: JOEL - JEM 2100). The samples' optical absorption and transmittance were recorded using a UV-Vis spectrophotometer (V-670-JASCO) at room temperature in the 
wavelength range of 300-1200 $\mathrm{nm}$. The electrical properties of the prepared nano samples were studied by the Four-probe method.

\subsection{Measurement of photocatalytic activity}

Experiments were carried out in a photocatalytic quartz reactor having a capacity of $150 \mathrm{ml}$. The reactor has facilities for water circulation to ensure a constant temperature. The UV irradiation was carried out using a $125 \mathrm{~W}$ $(311 \mathrm{~nm})$ medium pressure $\mathrm{Hg}$ arc lamp (SAIC, INDIA). $150 \mathrm{ml}$ of desired initial concentration (20 ppm) of Methylene blue dye solution was mixed with a fixed amount of Methylene blue NPs (50 mg/L) at natural pH (6.2). The solution was placed under UV illumination and was magnetically stirred. The sample from the photoreactor is withdrawn at different time intervals and centrifuged. The supernatants are analyzed for their absorption maximum (554nm) using UV-Vis Spectrophotometer. A similar procedure was adopted for metal $(\mathrm{Cu} \& \mathrm{Mn})$ dopants Methylene blue NPs using Methylene blue dye solution. The percentage of Methylene blue degraded by the catalyst surface was calculated from the following equation.

\section{Percentage of degradation $=\left(C_{0}-C_{t}\right) / C_{0} \times 100 \%$}

$\mathrm{C}_{\mathrm{O}}$ represents the initial time of absorption, and $\mathrm{C}_{\mathbf{t}}$ represents the absorption after various intervals of time.

\section{Results and discussions.}

\subsection{Structural analysis}

The X-ray diffraction patterns of the pure and metal-doped ( $\mathrm{Cu}$ and $\mathrm{Mn}$ ) $\mathrm{In}_{2} \mathrm{~S}_{3} \mathrm{NPs}$ are presented in Fig 1 . XRD pattern indicates that all the samples exhibit polycrystalline nature, and all the diffraction peaks can be attributed to the cubic phase of $\operatorname{In}_{2} \mathrm{~S}_{3}$ [24]. It is in good agreement with JCPDS data (JCPDS 01-084-1385) and earlier reported literature [25]. The highly intense diffraction peak corresponds to the (112) plane assigned to the diffraction angle, $2 \theta=28.3^{\circ}$. It is also noted that no new phases are observed after $\mathrm{Cu}$ and $\mathrm{Mn}$ doping, which means no change in the structure of $\operatorname{In}_{2} \mathrm{~S}_{3}$ due to the incorporation of $\mathrm{Cu}$ or $\mathrm{Mn}$. It is under the previously reported work [26-27].

Further, the crystalline system is not altered due to the metal doping since the metal ions occupy only the substitutional positions or voids because of their smaller ionic radii compared with $\operatorname{In}^{3+}$. From the XRD patterns, the peak intensity is maximum for $\operatorname{In}_{2} S_{3}$ NPs. It may be due to the improvement in the crystallinity of the pure $\mathrm{In}_{2} \mathrm{~S}_{3}$ samples [28]. 
The average crystallite size (d) can be estimated from the most substantial diffraction peak (112) using the Debye-Scherrer formula [29].

$$
d=\frac{0.89 \lambda}{\beta \cos \theta}
$$

Here, $\lambda$ is the wavelength of the $\mathrm{CuK} \alpha$ radiation line, $\beta$ is the full width at half-maximum (FWHM) of the preferred orientation (112), and $\theta$ is the corresponding diffraction angle (Bragg's angle). The average grain size was calculated, and it was found to be in the range between 36.2 and $49 \mathrm{~nm}$ corresponding to the prominent (112) peak. From Table1, it is noted that the crystallite size decreases with metal doping. It may be due to the smaller ionic radius of $\mathrm{Cu}^{2+}(0.73 \AA)$ and $\mathrm{Mn}^{2+}(0.70 \AA)$ compared to that of $\operatorname{In}^{3+}(0.81 \AA)$, which results in the creation of compressive stress in the doped NPs [30]. Further, the decrease in crystallite size in doping is due to creating new nucleation centres, changing the homogeneous nucleation to heterogeneous [31].

From XRD results, the microstrain ( $\varepsilon$ ) of the NPs calculated using the following formula [32].

$$
\varepsilon=\beta_{h k l} \cos \theta / 4
$$

Where $\beta$ is full-width at half maximum in radians and $\theta$ is Bragg's angle. The value of micro-strain $(\varepsilon)$ is found to be $0.651 \times 10^{-3}, 1.11 \times 10^{-3}$ and $6.95 \times 10^{-3}$ for $\operatorname{In}_{2} S_{3}, C u: \operatorname{In}_{2} S_{3}$ and $\mathrm{Mn}$ : $\operatorname{In}_{2} \mathrm{~S}_{3} \mathrm{NPs}$, respectively. The micro-strain is lower for $\operatorname{In}_{2} \mathrm{~S}_{3}$ NPs reveals the decrease in the concentration of lattice imperfections [33]. It is also noted that the strain value is higher for metal doping NPs due to the compressive stress created in the $\mathrm{In}^{3+}$ ions substitution by $\mathrm{Cu}^{2+}$ or $\mathrm{Mn}^{2+}$ in the lattice [25].

The dislocation density $(\delta)$ defined as the length of dislocation lines per unit volume. The dislocation density is one of the crystallographic defects that determine the properties of the material. The dislocation density ( $\delta$ ) is calculated using the following formula [34]

$$
\delta=\mathrm{I} / \mathrm{D}^{2}
$$

Where $\mathrm{D}$ is the crystallite size. The value of dislocation density $\left(\delta\right.$ ) is found to be $0.416 \times 10^{15}, 0.566 \times 10^{15}$ and $0.763 \times 10^{15}$ lines $\mathrm{m}^{-2}$ for $\operatorname{In}_{2} \mathrm{~S}_{3}, \mathrm{Cu}$ : $\mathrm{In}_{2} \mathrm{~S}_{3}$ and $\mathrm{Mn}$ : $\operatorname{In}_{2} \mathrm{~S}_{3}$ NPs respectively. The value of dislocation density is lower for $\operatorname{In}_{2} \mathrm{~S}_{3}$ NPs reflects high crystallinity and lower structural defects [35]. This result is a good agreement with the XRD results. The variation of micro-strain $(\varepsilon)$ and dislocation density $(\delta)$ are presented in Table 1 . From 
Table 1, it is noted that due to metal doping, the micro-strain and dislocation density is increased with a decrease in crystallite size and increase in the concentration of crystal imperfections.

\subsection{Field emission scanning electron microscope (FE-SEM) analysis:}

FE-SEM micrographs of the pure and metal-doped ( $\mathrm{Cu}$ and $\mathrm{Mn}$ ) $\mathrm{In}_{2} \mathrm{~S}_{3}$ NPs are presented in Fig 2(a-d). The FE-SEM micrographs reveal that many nanostructures are distributed on the surface of the prepared nano samples. These nanostructures can be used as gas sensors, dye-synthesized solar cells, and energy storage devices [36]. Fig 2.a indicates that spherical grains were uniformly distributed on the surface, and no needle-shaped grains were observed for the pure $\operatorname{In}_{2} \mathrm{~S}_{3}$ nano sample. The FE-SEM image of the $\mathrm{Cu}$ : $\mathrm{In}_{2} \mathrm{~S}_{3}$ sample demonstrates the growth of smooth and homogeneous nanoflowers are formed on the surface (Fig 2.b). Also, it was noted that the surface morphology was changed after metal doping $(\mathrm{Cu}$ or $\mathrm{Mn})$ with the base material of $\operatorname{In}_{2} \mathrm{~S}_{3}$. Fig 2.c and 2.d show the surface morphology of the $\mathrm{Mn}$ : $\operatorname{In}_{2} \mathrm{~S}_{3}$ sample. From the micrographs (2.c and 2.d), we noted that the grains deposited on the surface were a needle-like shape. Besides the needle grains, small spherical grains were found distributed throughout the surface. Further, the grains become smaller after incorporating Mn, which agrees with the XRD results.

\subsection{Energy dispersive spectral analysis (EDS)}

Energy dispersive spectral analysis (EDS) is employed to exhibit the elemental analysis of the prepared NPs. The EDS spectrum of pure and metal-doped (Cu and $\mathrm{Mn}) \mathrm{In}_{2} \mathrm{~S}_{3}$ NPs is shown in Fig 3(a-c). From the EDS spectrum, the intense peaks indicating the presence of indium (In), Copper (Cu), Manganese (Mn) and Sulphur (S) in the nano samples. Also, it is clearly observed that Oxygen $(\mathrm{O})$ content is present in all the samples. The oxygen is chemisorbed [37], and the oxygen-containing phase is formed during the growth process. These oxygen atoms are bonded at the surface and grain boundaries and do not enter into the crystallites [38-39]. Therefore, the properties of prepared nano samples are not altered by oxygen content. Further, the EDS analysis reflects that the composition is stoichiometric, and no other foreign elements are present in the nano samples.

\subsection{Optical studies}

The optical transmittance spectra of pure and metal-doped $\operatorname{In}_{2} S_{3}$ NPs in the wavelength range 300 to 1000 $\mathrm{nm}$ are presented in Fig 4. All the nano samples show good transparency in the visible region from the transmittance spectra and exhibit a sharp drop near the band edge. Further, the transmission is decreased after the 
metal doping, and there is a shift of the total absorption towards a shorter wavelength. It is also observed that the transmittance is low in the Ultraviolet (UV) region, whereas in the Visible (VIS) and infrared (IR) regions, high transmittance was observed. The high transparency in the VIS and IR regions is a consequence of the wide bandgap of the nano samples [40]. In the lower wavelength (UV) region, all the incident lights are observed by the atoms, and therefore less (or) no transmission occurs in this region [41].

Further, the high optical transmittance property is observed for pure $\operatorname{In}_{2} S_{3}$ NPs. It may be due to the improved sample's structural homogeneity and better crystallinity [42]. Materials with low absorbance and low reflectance in the VIS region make the samples suitable for suitable antireflection coating in solar cells working mainly in the VIS region [43].

The optical absorption spectrum of pure and metal-doped (Cu, Mn) $\mathrm{In}_{2} \mathrm{~S}_{3}$ NPs in the wavelength range 300$1000 \mathrm{~nm}$ are presented in Fig 5. The absorption spectrum is noted that the optical absorption is high in the UV region (band edge) and gradually decreases in the VIS and IR regions. At the UV region, the incident photon has enough energy to excite the electrons from the Valence band to the Conduction band, which results in high absorption in the UV region [44]. The absorption decreases in the higher wavelength regions corresponding to the reduction in the photon's energy. The enhanced absorption in the lower wavelength region makes the nano samples a good window layer for solar applications [41]. On the other hand, the low absorption in the VIS-IR regions makes the pure and metal $(\mathrm{Cu}, \mathrm{Mn})$ doped $\operatorname{In}_{2} \mathrm{~S}_{3}$ NPs useful for optical components in high laser window and multispectral applications, providing good imaging characteristics [41]

The absorption coefficient was calculated by using the Urbach relation [45].

$$
\alpha=A\left(h v-E_{g}\right)^{n} / h v
$$

$\mathrm{A}$ is a constant, $\mathrm{E}_{\mathrm{g}}$ is the bandgap energy, $v$ is the frequency of the incident radiation, and $\mathrm{h}$ is Planck's constant. The exponent ' $n$ ' is $1 / 2$ for the direct allowed transition. The absorption coefficient of pure and metaldoped $(\mathrm{Cu}$ and $\mathrm{Mn})$ is of the order of $\left(10^{5} \mathrm{~cm}^{-1}\right)$, which supports the direct bandgap nature of the semiconductor. It also noted that the absorption coefficient of the NPs increases with doping with an increase in the absorbance of nano samples with doping enhance an increment in their absorption coefficient [46].

The optical band gap energy of pure and metal $(\mathrm{Cu}, \mathrm{Mn})$ doped $\mathrm{In}_{2} \mathrm{~S}_{3}$ NPs was calculated from the Tauc plot [47]. 


$$
\alpha h v=A\left(h v-E_{g}\right)^{1 / 2}
$$

$\alpha$ is the absorption coefficient, hv is photon energy, $\mathrm{A}$ is constant, and $\mathrm{E}_{\mathrm{g}}$ is the bandgap energy. The interception of $(\alpha h v)^{2}$ versus photon energy plots gives the optical band gap energy value of the prepared nano samples at room temperature. The obtained band gap energy value for $\operatorname{In}_{2} S_{3}, C u$ : $\operatorname{In}_{2} S_{3}$ and $M n$ : $\operatorname{In}_{2} S_{3} N P s$ are 2.8 , 3.15 and $3.28 \mathrm{e} \mathrm{V}$, respectively. It is observed that the bandgap energy is increases with metal $(\mathrm{Cu}$ and $\mathrm{Mn})$ doping. The increase in the bandgap is attributed to the size minimization of the nanoparticles due to $\mathrm{Cu}$ (or) $\mathrm{Mn}$ doping [48]. The increase in bandgap energy due to doping is helpful for photovoltaic applications since it increases the absorption of photons in the UV region [49].

The extinction coefficient $(\mathrm{K})$ in the fundamental absorption section is calculated using the following equation [50].

$$
K=\frac{\alpha \lambda}{4 \pi}
$$

$\alpha$ is the absorption coefficient of the material specimen, and $\lambda$ is the wavelength of the incident light. The variation of extinction coefficient with pure and metal-doped $\operatorname{In}_{2} \mathrm{~S}_{3}$ NPs is presented in Table 2. From Table 2, the extinction coefficient is low for as prepared $\operatorname{In}_{2} \mathrm{~S}_{3}$ NPs, and it is slightly increased with metal doping [51]. It may be due to the strong absorption and less transmission of light in the UV region.

\subsection{Dielectric studies.}

The relation between refractive index $(n)$ and bandgap energy $\left(\mathrm{E}_{\mathrm{g}}\right)$ is given by the Herve-Vandamm formula [52]

$n^{2}=1+184.96 /\left(E_{g}+3.4\right)^{2}$

The refractive index for $\operatorname{In}_{2} S_{3}, \mathrm{Cu}$ : $\operatorname{In}_{2} \mathrm{~S}_{3}$ and $\mathrm{Mn} \operatorname{In}_{2} \mathrm{~S}_{3}$ NPs are presented in Table 3. From Table 3, the refractive index of the grown nano samples decreases with doping [51]. The refractive index of the doped nano samples decreases with the increase of bandgap energy [53].

The natural and imaginary part of the dielectric constant was calculated by the following equations [54].

$$
\begin{aligned}
& \varepsilon_{1}=n^{2}-k^{2} \\
& \varepsilon_{2}=2 \mathrm{nk}
\end{aligned}
$$

$\varepsilon_{1}$ is the fundamental part of the dielectric constant, $\varepsilon_{2}$ is the imaginary part of the dielectric constant, $n$ is the refractive index, and $\mathrm{k}$ is the extinction coefficient. The calculated value of $\varepsilon_{1}$ and $\varepsilon_{2}$ are presented in Table 3 . From 
Table 3, it is noted that the genuine part dielectric constant $\left(\varepsilon_{1}\right)$ increases with doping, whereas the imaginary part of dielectric constant $\left(\varepsilon_{2}\right)$ decreases with metal doping. Our result is in good agreement with Mahdi H. Suhail (2012) [54].

The standard incidence reflectance $(\mathrm{R})$ was calculated by using the following relation [55]

$$
R=(n-1)^{2}+\frac{k^{2}}{(n+1)^{2}}+k^{2}
$$

Where $\mathrm{n}$ is the refractive index and $\mathrm{k}$ is the extinction coefficient. The calculated value of reflectance $(\mathrm{R})$ is presented in Table 3. From Table 3, it was observed that the reflectivity slightly increases with doping. It is also noted that the overall reflectance of all the samples is low. The high transmission and low reflectance values obtained makes the nano samples suitable as anti-reflecting coating materials for photovoltaic applications [45].

\subsection{Photoluminescence studies (PL)}

Photoluminescence studies monitor the electronic transition of photo-excited atoms (or) molecules. The excited atoms make a transition via either radiative (or) non-radiative processes [56]. In radiative transition, the energy is emitted in the form of photons. PL spectra of pure and metal-doped $\operatorname{In}_{2} \mathrm{~S}_{3}$ NPs are obtained at room temperature with an excitation wavelength of $350 \mathrm{~nm}$ is shown in Fig 7. From Fig 7, four intense peaks are observed in the wavelength range between 540 and $650 \mathrm{~nm}$. This feature corresponds to the donor-acceptor pair transition (DAP) between a sulphur vacancy $\left(\mathrm{V}_{\mathrm{S}}\right)$ and an indium vacancy $\left(\mathrm{V}_{\mathrm{In}}\right)$ (or) copper (or) manganese on an indium site [57-58]. It is noted that the incorporation of metal doping ( $\mathrm{Cu}$ and $\mathrm{Mn})$ will shift the peak slightly towards the shorter wavelength region (higher energy). This result may be related to the increase in the bandgap energy, which is in good agreement with the optical analysis [59].

Further, the peak intensity increases with metal doping confirm the better crystallinity with few electronic defects and good dispersity of nanomaterials [60]. From PL spectra, the inhomogeneous broadening of peaks is noted for metal doping reveals the presence of defect centres [61]. The luminescence emission at $595 \mathrm{~nm}$ is known as green emission. The green emission is due to the transition between donors created by sulphur vacancies ( $\left.\mathrm{V}_{\mathrm{S}}\right)$ and acceptors due to the indium vacancies $\left(\mathrm{V}_{\text {In }}\right)$ [62]. The observed luminescence at $615 \mathrm{~nm}$ is associated with indium interstitials (or) due to the sulphur vacancies ( $\mathrm{V}_{\mathrm{S}}$ ) and sulphur interstitials [63]. The emission peak for Mn: 
$\mathrm{In}_{2} \mathrm{~S}_{3}$ NPs consists of two components at wavelength 582, and $635 \mathrm{~nm}$ is probably due to the possibility of double structure in the sulphur vacancy $\left(\mathrm{V}_{\mathrm{S}}\right)$, which may act as a doubly ionized donor [64].

\subsection{Electrical Studies}

The resistivity of the NPs depends on several factors like preparation parameters, doping agent, temperature and the dimension of the NPs. The following equations have calculated the electrical resistivity $(\rho)$ and conductivity ( $\sigma$ ) of the prepared NPs.

$$
\begin{gathered}
\rho=1665\left(\frac{V}{I}\right) \\
\sigma=\frac{1}{\rho}
\end{gathered}
$$

$\mathrm{V}$ is the voltage in Volts, and $\mathrm{I}$ is the current in Amperes. The variation of conductivity with metal doping is presented in Table 4. from table 4. It is noted that the conductivity is higher for as prepared $\operatorname{In}_{2} \mathrm{~S}_{3} \mathrm{NPs}$, whereas in metal doping, the conductivity is decreased [65-66]. Since the charge transport is predominantly intra-grain in the case of more prominent grain NPs, there is a substantial improvement in the conductivity, whereas, in the case of smaller grain NPs, the higher number of grain walls may act as low conductivity blockades [67]. The higher conductivity might be due to the decrease of residual defects and increase of crystallite size of NPs [68]. Further, the increase in crystal size allows a decrease in electron scattering, leading to an increase in electrical conductivity [69]. The high value of conductivity (low resistivity) of $\operatorname{In}_{2} \mathrm{~S}_{3}$ NPs exhibit the semiconducting property and find wide applications in the field of optoelectronics [70].

\subsection{Photocatalytic studies}

The photocatalytic activity of pure and metal $(\mathrm{Cu}, \mathrm{Mn})$ doped $\operatorname{In}_{2} \mathrm{~S}_{3}$ NPs with Methylene blue (MB) dye solution was studied under different intervals of time (0-120 min). Methylene blue is one kind of organic dye and often used as a pollutant to study the photocatalytic activity of nanomaterials. In this study, methylene blue is an object to investigate the photocatalytic degradation properties of the as-prepared and metal-doped $\operatorname{In}_{2} \mathrm{~S}_{3} \mathrm{NPs}$ with the help of UV-Vis absorption spectra. The optical absorption spectra of Methylene blue dye solution at a different time interval (0-120min) is presented in Fig.8 (a-c). It is observed that with the lapse of time, the peak height was decreasing by the incorporation of more significant degradation of Methylene blue due to the photocatalytic activity of $\mathrm{Cu}$ and $\mathrm{Mn}$ towards $\mathrm{In}_{2} \mathrm{~S}_{3}$. Our study observes that the size of the nanoparticles can play a significant 
role in photocatalytic efficiency. The lowest efficiency is observed for the sample of $\operatorname{In}_{2} \mathrm{~S}_{3}$, which has the largest crystalline size of $49 \mathrm{~nm}$ (Table1), and the sample with intermediate crystallite size have shown better photocatalytic efficiency. A small amount of dye was degraded using pure $\operatorname{In}_{2} \mathrm{~S}_{3}$ after 120 minutes, whereas for Mn-doped sample showed higher degradation efficiency. This is anticipated due to the presence of defects and oxygen vacancies created by Mn doping inside the $\operatorname{In}_{2} \mathrm{~S}_{3}$ matrix [71].

Mn-doped Methylene blue NPs shows a significant enhancement of the photodegradation of Methylene blue dye compared to the pure and $\mathrm{Cu}$ doped $\operatorname{In}_{2} \mathrm{~S}_{3}$ NPs. The enhanced photocatalytic activity for Mn-doped Methylene blue NPs is due to its enlarged surface area with surface oxygen vacancies [72]. In this research, Mndoped Methylene blue NPs show better photocatalytic properties after 120 min compared to pure $\operatorname{In}_{2} \mathrm{~S}_{3}$ sample. This might be due to the change in their particle size and band gap effects [73]. The degradation rate constant is calculated by the following equation [74].

$$
\operatorname{In}\left(\frac{\mathrm{C}_{\mathrm{o}}}{\mathrm{C}}\right)=k t
$$

$\mathrm{Co}$ and $\mathrm{C}$ are the reactant concentration at time $\mathrm{t}=0$ and $\mathrm{t}=\mathrm{t}, \mathrm{k}$ is the First-order rate constant, and $\mathrm{t}$ is time. The linear plot, the rate constant $(\mathrm{k})$ for the degradation of Methylene blue dye for pure and metal $(\mathrm{Cu}, \mathrm{Mn})$ doped In2S3 NPs, is determined and presented in Table 5. From Table 5, it is observed that the degradation rate constant (k) increases with doping and the high degradation rate constant demonstrates high photocatalytic activity [75].

The obtained degradation rate constant (k) for $\operatorname{In}_{2} S_{3}, \mathrm{Cu}$ : $\operatorname{In}_{2} \mathrm{~S}_{3}$ and $\mathrm{Mn}$ : $\operatorname{In}_{2} \mathrm{~S}_{3}$ NPs are $0.00064,0.00101$ and 0.00601 respectively. Among them, the $\mathrm{Mn}$ : $\operatorname{In}_{2} \mathrm{~S}_{3}$ NPs exhibited the highest degradation rate constant (k) value. Thus the collective effects of the increased surface area and the small size nanoparticles induce better photocatalytic performance for the metal-doped nanoparticles compared with $\operatorname{In}_{2} \mathrm{~S}_{3}$ NPs [76]. The findings of this photocatalytic experiment reveal that the doping of $\mathrm{Mn}^{2+}$ ions can effectively enhance the photocatalytic activity of Methylene blue photo-catalyst.

\subsubsection{Mechanism of Photocatalysis.}

The photodegradation of Methylene blue dye in the presence of visible light is presented in Fig 10. The flash of light irradiates on prepared NPs, the electrons in the valence band (VB) is excited into the conduction band (CB), leaving holes in the VB. Meanwhile, adsorbed oxygen molecules are converted into superoxide free radical 
by accepting the electrons from CB. Simultaneously adsorbed water molecules on the particle surface also dissociated into $\mathrm{H}^{+}$and $\mathrm{OH}^{-}$. Further, the hydroxyl ion interacts with a VB hole and gets converted into a hydroxyl radical by transferring the electron to VB. Later this hydroxyl radical reacts with Methylene blue and converts into degraded products.

The mechanism for the photocatalytic degradation of methylene blue can be represented as follows.

$$
\begin{aligned}
& \mathrm{In}_{3} \mathrm{~S}_{3}+\mathrm{hv} \rightarrow \mathrm{In}_{3} \mathrm{~S}_{3}\left(\mathrm{e}^{-}+\mathrm{h}^{-}\right) \\
& \mathrm{O}_{2}+\mathrm{e}^{-} \rightarrow \mathrm{O}_{2}- \\
& \mathrm{H}_{2} \mathrm{O} \rightarrow \mathrm{H}^{+}+\mathrm{OH}^{-} \\
& \mathrm{h}^{+}+\mathrm{OH}^{-} \rightarrow \mathrm{OH}
\end{aligned}
$$

$\mathrm{OH}, \rightarrow$ Methylene blue $\rightarrow$ Photodegraded products.

\section{Conclusion}

A comprehensive study of the influence of metal doping on structural, optical, electrical and photocatalytic properties of $\operatorname{In}_{2} S_{3}$ NPs is presented. The XRD pattern indicates that all the nano samples exhibit cubic $\operatorname{In}_{2} \mathrm{~S}_{3}$ phase with a preferential growth direction (112) plane. Further, the crystalline system is not altered due to the metal doping since the metal ions occupy only the substitutional positions because of their smaller ionic radii compared with $\mathrm{In}^{3+}$ ions. Due to doping, the crystallite size decreased from 49 to $36.2 \mathrm{~nm}$. FESEM studies reveal that the surface morphology was changed after metal doping $(\mathrm{Cu}$ or $\mathrm{Mn})$ with the base material of $\operatorname{In}_{2} \mathrm{~S}_{3}$. EDS spectra confirm the presence of In, S, Cu and Mn elements in the prepared NPs. Optical studies have shown that the visible region's transmittance value is about $80 \%$, and the optical band gap increased from 2.8 to $3.28 \mathrm{e} \mathrm{V}$ due to metal doping. From PL studies, the inhomogeneous broadening of peaks is noted for metal doping reveals the presence of defect centres. The electrical studies indicate that the lower value of resistivity is obtained for metal doping. The findings of this photocatalytic experiment reveal that the doping of $\mathrm{Mn}^{2+}$ ions can effectively enhance the photocatalytic activity of Methylene blue photo-catalyst. The high transmittance and low resistivity make the nano samples convenient for optoelectronic applications. In summary, metal doping plays an essential role in varying the physical properties of the prepared NPs.

\section{References}


[1] KP Vijayakumar, Semic. Sci. Techn. 18 (2003) 491. [1] L.C. Pathak, T.B. Singh, S,Das, A.K.Verma, P.

Ramachandrarao, Mater. Lett. 57 (2002) 380-385.

[2] Z. Wang, Y. Liu, Z. Zhang, Hand book of nanophase and nanostructure material, (2002).

[3] S.C. Kuiry, E. Megen, S.D. Patil, S.A. Deshpande, S. Seal, J. Phy Chem B. 109 (2005) 3868-3872.

[4] MK Patra, K. Manzoor, M. Manoth, S.C. Negi, S.R. Vadera, N. Kumar, Defence Science Journal, 58 (2008) 636-649.

[5] Dhiraj Patil, Dattatray chopade, Manoj Kumbhalkar, Mayfeb, J. Mech. Engi. 1 (2018) 1-12.

[6] T.T. John, S. Bini, Y. Kashiwaba, T. Abe, Y. Yasuh, C.S. Kartha

[7] T.T. John, M. Mathew, C.S. Kartha, K.P. Vijayayaku, T. Abe, Y. Kashiwaba, Sol. Energy

Mater. Sol. Cells. 89 (2005) 27.

[8] N. Barreaua, J.C. Bernede, C, Deudon, L. Brogan, S. Marsillac, J. Cryst. Growth 241 (2002) 4-

[9] M. Lainef, H. Ezzaouia, Open. Appl. Phys. J. 2 (2009) 23-26.

[10] A. Timoumi, H. Bouzouita, Int. J. Renew. Energy Technol. Res. 2 (2013) 188-195.

[11] ZQ. Yan, Y. Zhao, M.X. Zhuang, J. Liu, A.X. Wei, J. Mater. Sci. Mater. Electron. 24 (2013) 5055.

[12] R. Nomura, K. Konishi, H. Matsuda, Thin. Solid. Films. 198 (1991) 339-345.

[13] N. Barreau, A. Mokrani, F. Couzinic- Devy, J. Kessler, Thin. Solid. Films. 517 (2009) 2316-2319.

[14] R.N. Bekimbetiv, Yu.V. Rud, M.A. Tiarov, Fiz. Tekhn. Polupr. 21 (1987) 1051.

[15] R.K. Sharma, Gurmeet Singh, A.C. Rastogi, Solar Energy Mater. Solar Cells. 82 (2004) 217.

[16] C. Mahendran, N. Suriyanarayan, Mater. Sci. Semicon. Proc. 15 (2012) 522-530.

[17] M. Nguefack, A.F. Popa, S. Rossignol, C. Kappenstein, Chem. Chem. Phys. 5 (2003) 4279-4289.

[18] D. Mishara, S. Anand, R.K. Panda, R.K. Das, Mater. Lett. 42 (2000) 38-45.

[19] O. Rahmanpour, A. Shariati, MR Khosravi Nikou Int. J. Chem. Eng. Appl. 3(2) (2012) 125-128.

[20] K. Kamata, T. Mochizuki, S. Matsumoto, A.Yamada, K. Miyokawa, J. Am. Ceram. 68 (1985) 193-194.

[21] X. Wang, G. Lu, Y. Wang, Y. Geo, Mater. Chem. Phys. 90 (2005) 225-229.

[22] S.C.Ghosh, Y.Boontongkong, C.Thanachayanont, J.Dutta, M.K. Hossain, Metastab. Nanocryst. Mater. 23 (2015) 27-30.

[23] Hari-Bala Xiatang Lv. Xiaokun Ma, Fang Sun, Lanquin Tang, Zichen Wang, Minggang Li, Mater. Lett. 61 (2007) 690-693. 
[24] Lin Ling - Yan, Yu Jin- Ling, Cheng Shu -Ying, Lu Pei - Min, Chin. Phys. 24 (2015) 078103-1-078103-5.

[25] M. Kraini, N. Bouguila, J.EL. Ghoul, Indian, J. Phys. 92(8) (2018) 989-997.

[26] M. Mathew, R. Jayakrishnan, P.M. Ratheesh Kumar, C. Sudha Kartha, Y. Kashiwaba, K.P. Vijayakumar, J. Appl. Phys. 100 (2006) 33504.

[27] M. Mathew, M.Gopinath, C. Sudha Kartha, K.P. Vijayakumar, Y. Kashiwaba, T. Abe, Sol. Energy. 84 (2010) 888.

[28] S.R. Battacharyya, A.K. Pal, Bull. Mater. Sci. 31 (2008) 73-82.

[29] A. Mhamdi, B. Ouni, A. Amlouk, K. Boubaker, M. Amlouk, J. Alloys Compd. 582 (2014) 810-822.

[30] R.C. Weast, Handbook of Chemistry and Physics (Boca Raton: CRP Press) (1987) p.105.

[31] A. Mhamdi, B. Ouni, A. Amlouk, K. Boubaker, M. Amlouk, J. Alloy. Compd. 582 (2014) 810.

[32] M. Danam, R.P. Rajeev, P.K. Manoj, Mater. Chem. Phys. 107 (2008) 289-96.

[33] V. Bilgin, S. Kose, F. Atay, I. Akyuz, Mater. Chem. Phys. 94 (2005) 103-8.

[34] A. Kennedy, V. Senthil Kumar, K. Pradeev Raj, J. Phys. Chem. Solids. 110 (2017) 100-107.

[35] S.P. Choudhury, SD. Gunjal, N, Kumari, KD. Diwate, K.C. Mohite, A. Bhattacharjee, Materials Today: Proceedings. 3 (2016) 1609-1619.

[36] P. Yuvaraj, M. Ramamurthy, J. NanoSci. Nanotech. 4 (2014) 496-501.

[37] R.S. Berg, R.D. Nasby, J. Vac. Sci. Technol. 15 (1978) 359.

[38] R. Scheer, M. Alt. I. Luck, H.J. Lewerez, Sol. Energy Mater. Sol. Cells. 9 (1993) 423.

[39] C. Mahendran, N. Suriyanarayan, Phys. B. 408 (2013) 62-67.

[40] A. Aldrin, Preparation and characterization of certain II-VI, I-III-VI2 Semiconductor thin films and transparent conducting Oxides, Cochin University of Science and Technology, India, 2004.

[41] AU. Moreh, M. Momoh, B. Hamza, Int. J. Eng. Sci. Invent. 2(1) (2013) 48-52.

[42] B. Vijay, B. Sanap. H. Pawar, Int. J. Thin Films Sci. Technol. 2 (2013) 107-111.

[43] A. Bedia, F.Z. Bedia, M. Aillerie, N. Maloufi, B. Benyoucel, Ener. Proc. 74 (2015) 529-538

[44] Ahad. J. Hassan, J. Mod. Phys. 5 (2014) 2184-2191.

[45] T. Sivaraman, V.S. Nagarethinam, A.R. Balu, Res. J. Mater. Sci. 2(2) (2014) 6-15.

[46] Souad G. Kaleel, Mahdi H. Suhaal, Faten M. Yasser, Int. J. Emer. Tech. Advanc. Eng. 4(3) (2004) 613-621.

[47] J. Tauc, "Amorphous and Liquid Semiconductors", Plenum Press, New York (1974).

[48] M. Hassan Zadeh Maha, M.M. Bagher-Mohagheghi, H. Azimi-Juybari, 536 (2013) 57. 
[49] C. Guillen, T. Garcia, J. Herrero, M.T. Gutierrez, F. Briones, Thin. Solid. Films. 451.

[50] J.C. Manifacier, J. Gasiot, J.P. Fillard, Simple for the determination of the optical constants, 9 (1976) 10031004.

[51] K. Santhose Kumar, C. Manoharan, S. Dhanapandian, A. Gowri Manohari, T. Mahalingam, Optik 125 (2014) 3996-4000.

[52] P.J.L. Herve, L.K.J. Vandamme, J. Appl. Phys. 77 (1995) 5476.

[53] Jai Sing, "Optical Properties of Condensed Matter and Applications", Wiley Series in Materials for Electronic and Optoelectronic Applications, Jonn Wiley \& Sons Ltd, England (2006).

[54] Mahdi H. Suhail, Bull. Mater. Sci, 35(6) (2012) 947-956.

[55] F. Abeles, "Optical Properties of Solids", North Holland Publishing Company, London, UK (1972).

[56] M. Yan, L.J. Rothberg, F. Papadimitrakopoulos, M.E. Galvin, T.M. Miller, Phys. Rev. Lett. 73 (1994) 744.

[57] J. Van Gheluwe, J. Versluys, D. Poelman, J. Vershraegen, M. Burgelman, P. Chauws, Thin Solid Films. 511512 (2006) 304-308.

[58] M. Nanu, J. Schoonman, A. Goossens, Thin Solid Films. 193 (2004) 451-452.

[59] Mejda Ajili, Michel Castagne, Najoua Kamoun Turki, J. Lumin. 150 (2014) 1-7.

[60] Swarup Kumar Maji, Amit Kumar Dutta, Supriya Dutta, Divesh N. Srivastava, Parimal Paul, Anup Mondal, Bibhutosh Adhikary, Appl. Catal. B- Enciron. 126 (2012) 265.

[61] N. Suriyanarayanan, C. Mahendran, Mater. Sci. Engi. B. 176 (2011) 417-424.

[62] S. Elfarrass, B. Hartiti, A. Ridah, P. Thevenin, J. Mater. Environ. Sci. 6(2) (2015) 487-490.

[63] Abdel hak Jrad, Tarek Ben Nasr, Najoua Turki-Kamoun, Opti. Mater. ...(2015)

[64] C. Mahendran, N. Suriyanarayanan, Physica B. 405 (2010) 2009-2013.

[65] Z.B. Achour, T. Ktari, B. Ouertani, O. Touayar, B. Bessais, J.B. Brahim, Sens. Actuators A. 134 (2007) 447451.

[66] C.M Muiva, T.S. Sathiaraj, K. Maabong, Ceramics. Inter. 37 (2011) 555-560.

[67] K. Ravichandran, G. Muruganantham, B. Sakthivel, P. Philominathan, J. Ovonic. Res. 5(3) (2009) 63-69.

[68] Salah Abdul- Jabber Jassim, Abubaker A. Rashid Ali Zumaila, Gassan Abdella Ali Al Waly, Res. Phys. 3 (2013) 173-178. 
[69] Boen Houng, Chi Shiung His, Bing Yi Zhang \& Shen Li Fu, Vacuum, 83 (2009) 534.

[70] Panday P K, Bhave N S \& Kharat R B, Ind J Appl Phys, 44 (2006) 281.

[71] D. Sarkar, P.K. Giri Bappaditya Pal," App. Sur. Sci, 356 (2015) 804-811.

[72] M. S. Ramachandra Rao, Tatsuo Okada, ZnO Nanocrystals and Allied Materials: Springer Science \& Business Media, (2013) 278-279.

[73] Tuhin Kumar Maji, Damayanti Bagchi, Prasenjit Kar, Debjani Karmakar, Samir Kumar Pala, " J. Photochem. Photobiol. A Chem., 332 (2017) 391-398.

[74] E.Ahmed. Fezza Zafar, N.A. Khalid, N.A. Niaz. Abdul Hafeez, M. Ikram, M. Ajmal khan, M.Ahmad, J. Rare. Earths. 3 (2015) 254-262.

[75] Z. Barzgari, A. Ghazizadeh, S.Z. Askari, Res. Chem. Intermed. 42 (2015) 84303-84315.

[76] K. Pradeev Raj, K. Sadaiyandi, A. Kennedy, Suresh Sagadevan, J. Mater Sci: Mater Electron. DOI 10.1007/s 10854-017-7857-7.

\section{Figure caption}

Fig. 1. X-ray diffraction spectra of pure and metal $(\mathrm{Cu}, \mathrm{Mn})$ doped $\operatorname{In}_{2} \mathrm{~S}_{3} \mathrm{NPs}$.

Fig. 2(a-d) FE-SEM images of pure and metal (Cu, Mn) doped $\operatorname{In}_{2} \mathrm{~S}_{3}$ NPs. (a) $\operatorname{In}_{2} \mathrm{~S}_{3}$, (b) Cu: $\operatorname{In}_{2} \mathrm{~S}_{3}$, (c \& d) Mn: $\operatorname{In}_{2} \mathrm{~S}_{3}$.

Fig.3 (a-c). EDS spectra of pure and metal $(\mathrm{Cu}, \mathrm{Mn})$ doped $\mathrm{In}_{2} \mathrm{~S}_{3} \mathrm{NPs}$.

Fig. 4. Transmittance spectra of pure and metal $(\mathrm{Cu}, \mathrm{Mn})$ doped $\mathrm{In}_{2} \mathrm{~S}_{3} \mathrm{NPs}$

Fig. 5. Optical absorption spectra of pure and metal $(\mathrm{Cu}, \mathrm{Mn})$ doped $\operatorname{In}_{2} \mathrm{~S}_{3} \mathrm{NPs}$

Fig. 6. Optical bandgap energy $\left(E_{g}\right)$ of pure and metal $(\mathrm{Cu}, \mathrm{Mn})$ doped $\operatorname{In}_{2} \mathrm{~S}_{3} \mathrm{NPs}$

Fig. 7. PL spectra of pure and metal $(\mathrm{Cu}, \mathrm{Mn})$ doped $\mathrm{In}_{2} \mathrm{~S}_{3} \mathrm{NPs}$

Fig.8 (a-c). The photocatalytic activity of pure and metal (Cu, Mn) doped $\operatorname{In}_{2} \mathrm{~S}_{3}$ NPs with Methylene blue (MB) under different intervals of time (0-120 $\mathrm{min})$.

Fig 9. Kinetics of Methylene blue dye for pure and metal $(\mathrm{Cu}, \mathrm{Mn})$ doped $\operatorname{In}_{2} \mathrm{~S}_{3}$ NPs under UV-Visible radiation. 
Fig 10. Photodegradation of Methylene blue in Visible light.

\section{Table caption}

Table 1: Microstructural parameters of pure and metal $(\mathrm{Cu}, \mathrm{Mn})$ doped $\operatorname{In}_{2} \mathrm{~S}_{3}$ Nanoparticles.

Table 2: Optical parameters of pure and metal $(\mathrm{Cu}, \mathrm{Mn})$ doped $\mathrm{In}_{2} \mathrm{~S}_{3} \mathrm{NPs}$

Table 3: The Dielectric parameters of pure and $(\mathrm{Cu}, \mathrm{Mn})$ doped $\operatorname{In}_{2} \mathrm{~S}_{3}$ Nanoparticles

Table 4: Electrical parameters of pure and metal $(\mathrm{Cu}, \mathrm{Mn})$ doped $\operatorname{In}_{2} \mathrm{~S}_{3} \mathrm{NPs}$

Table 5: Photocatalytic degradation of for pure and $(\mathrm{Cu}, \mathrm{Mn})$ doped $\mathrm{In}_{2} \mathrm{~S}_{3}$ Nanoparticles. 
Figures

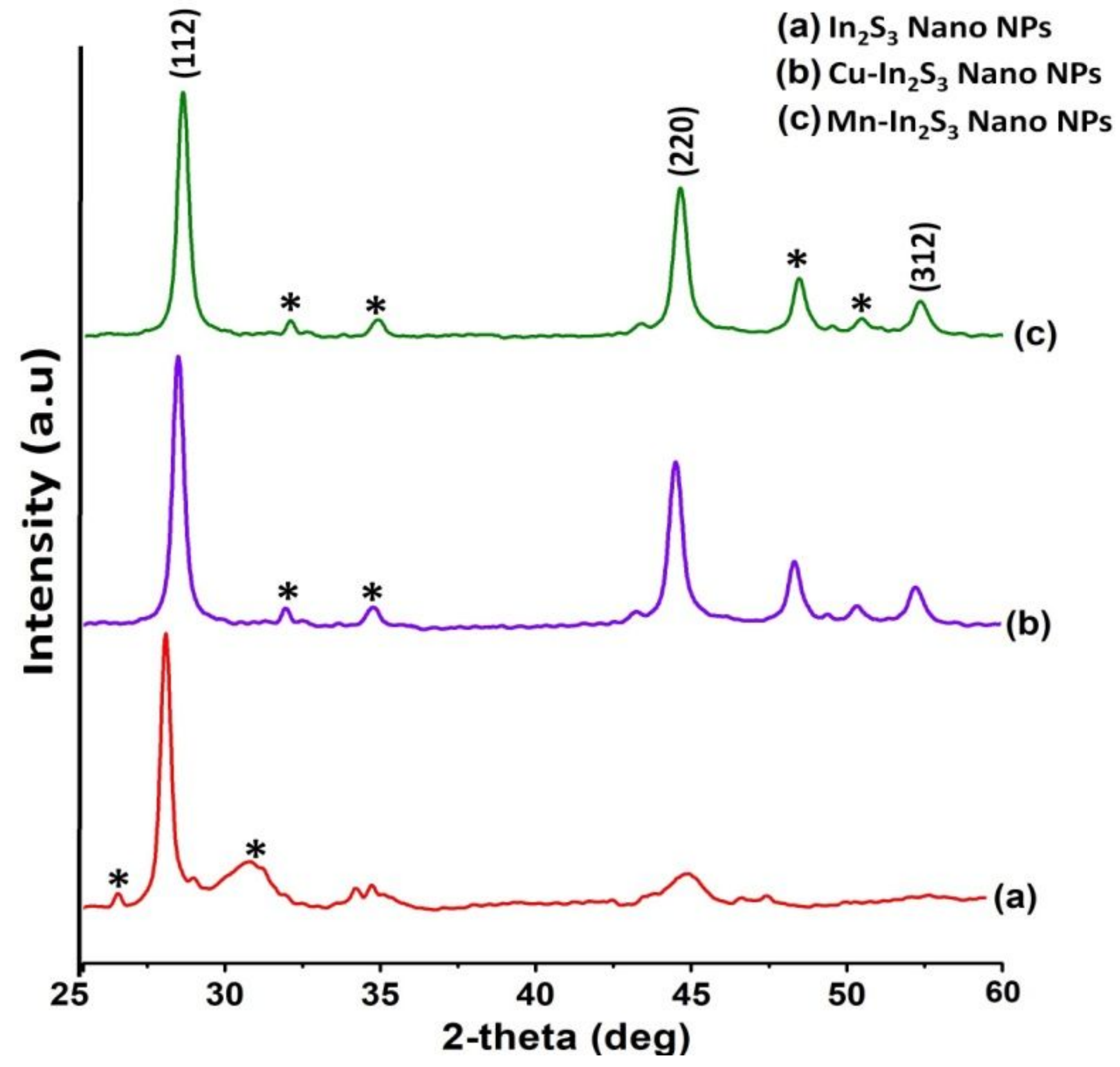

Figure 1

X-ray diffraction spectra of pure and metal (Cu, Mn) doped In2S3 NPs. 


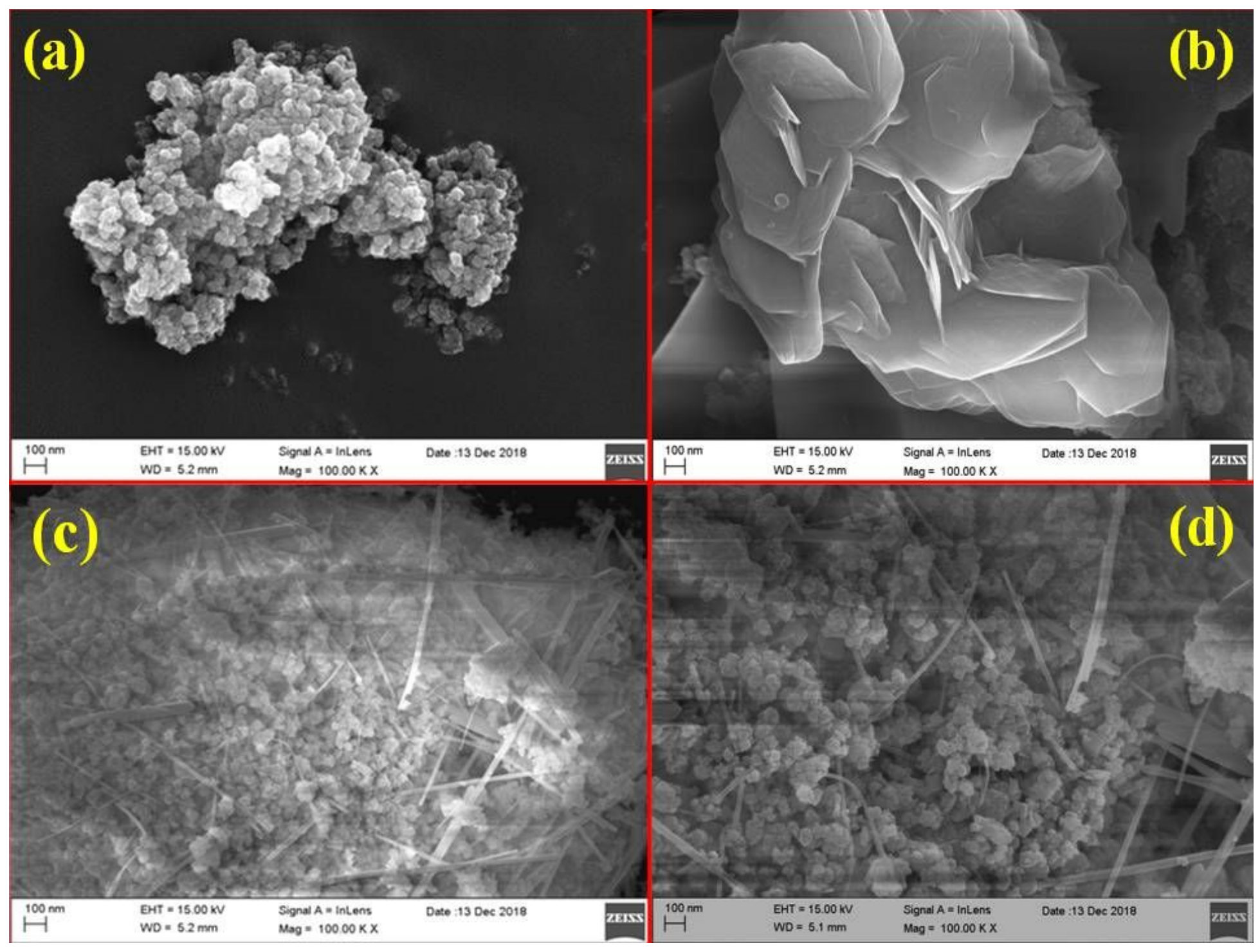

Figure 2

(a-d) FE-SEM images of pure and metal (Cu, Mn) doped In2S3 NPs. (a) In2S3, (b) Cu: In2S3, (c \& d) Mn: In2S3. 

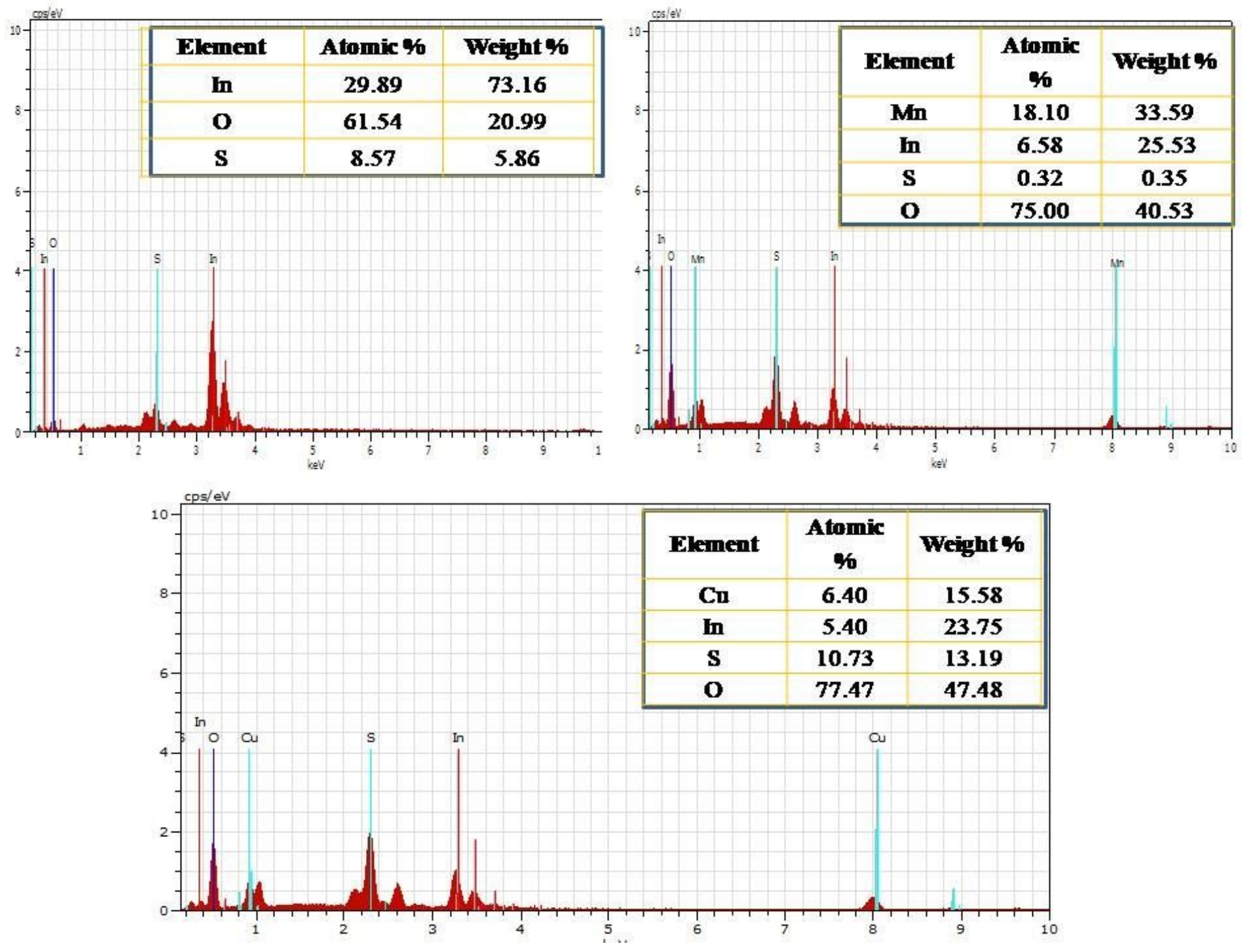

Figure 3

(a-c). EDS spectra of pure and metal (Cu, Mn) doped In2S3 NPs. 


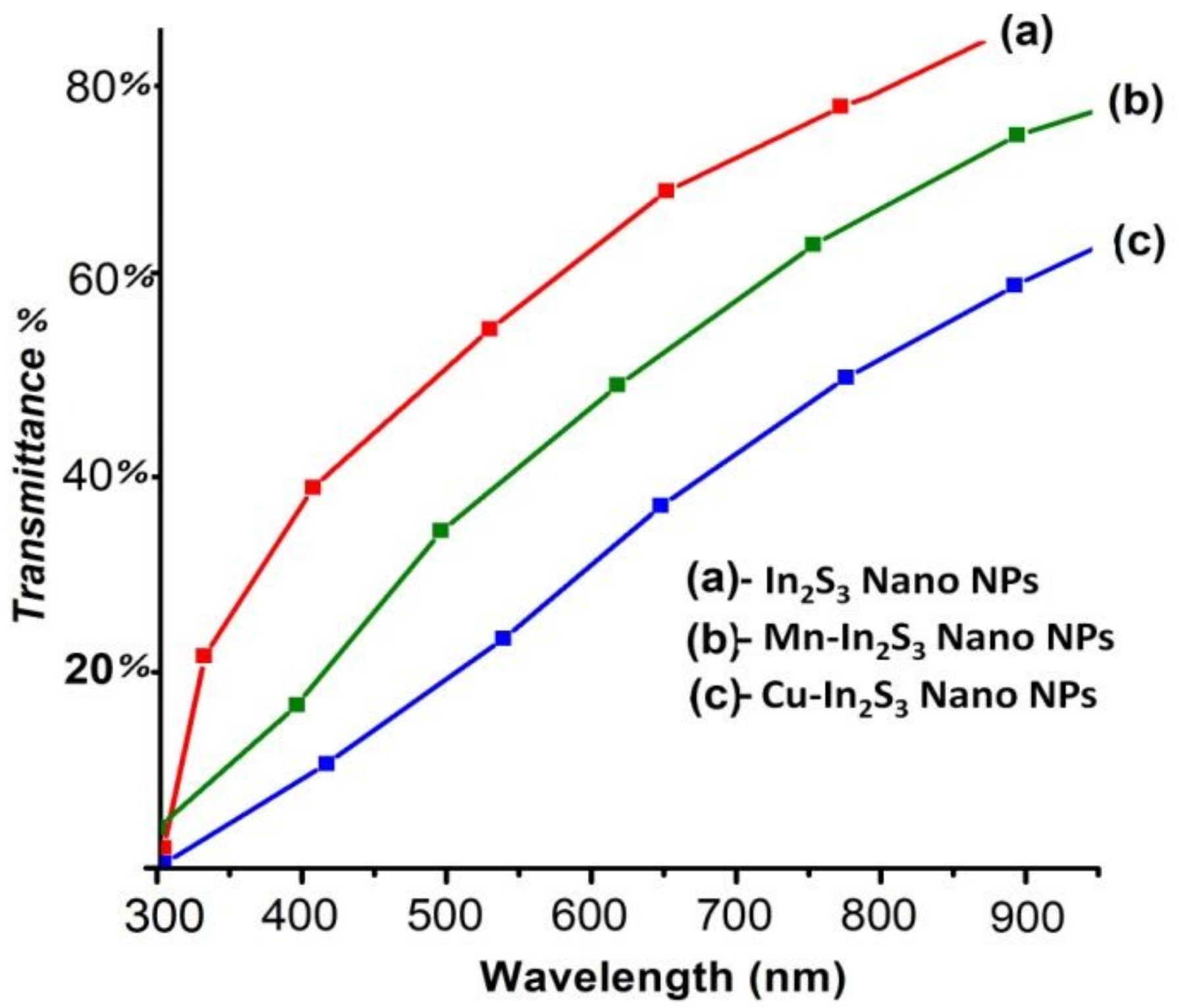

Figure 4

Transmittance spectra of pure and metal $(\mathrm{Cu}, \mathrm{Mn})$ doped In2S3 NPs 


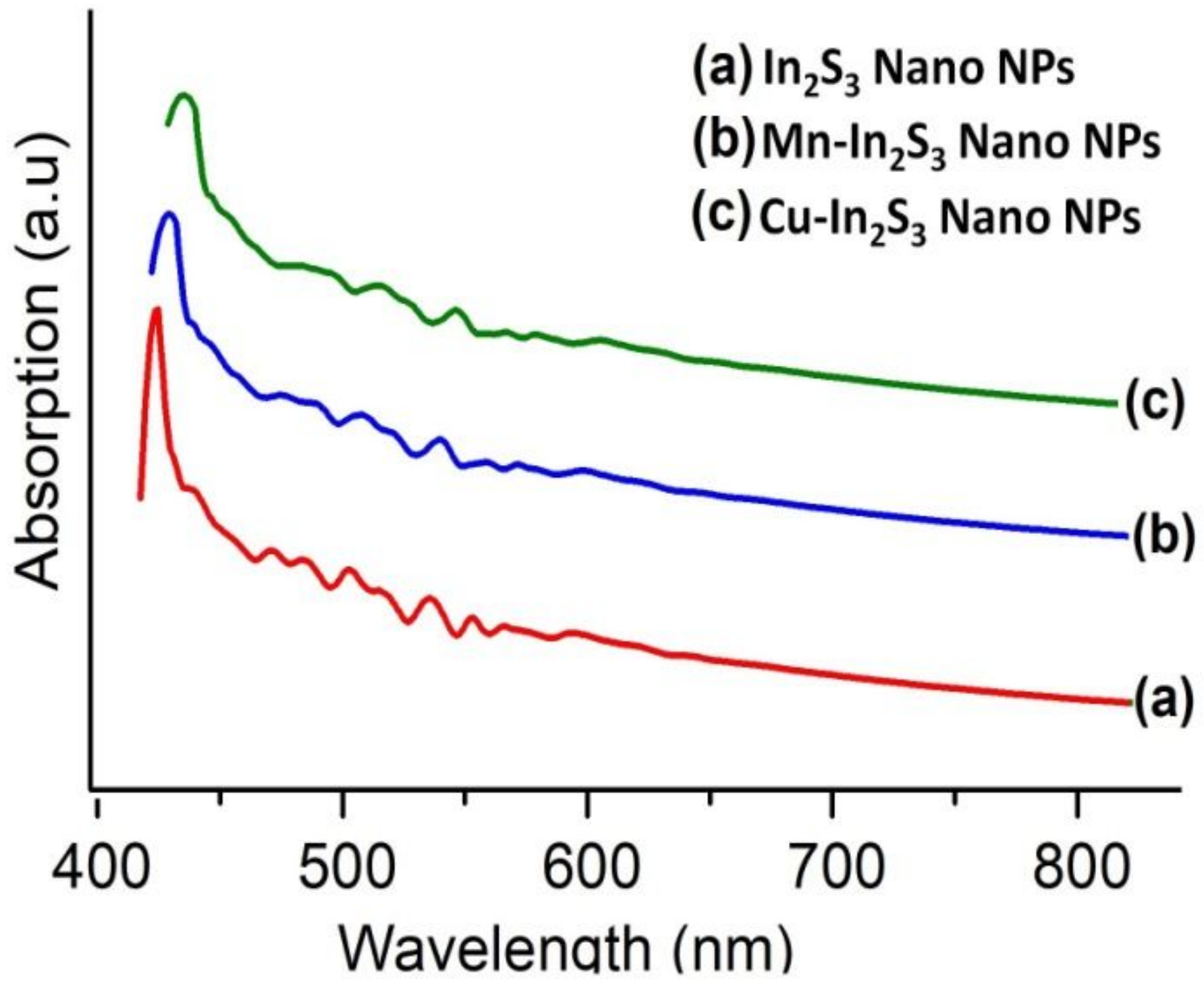

Figure 5

Optical absorption spectra of pure and metal (Cu, Mn) doped In2S3 NPs 


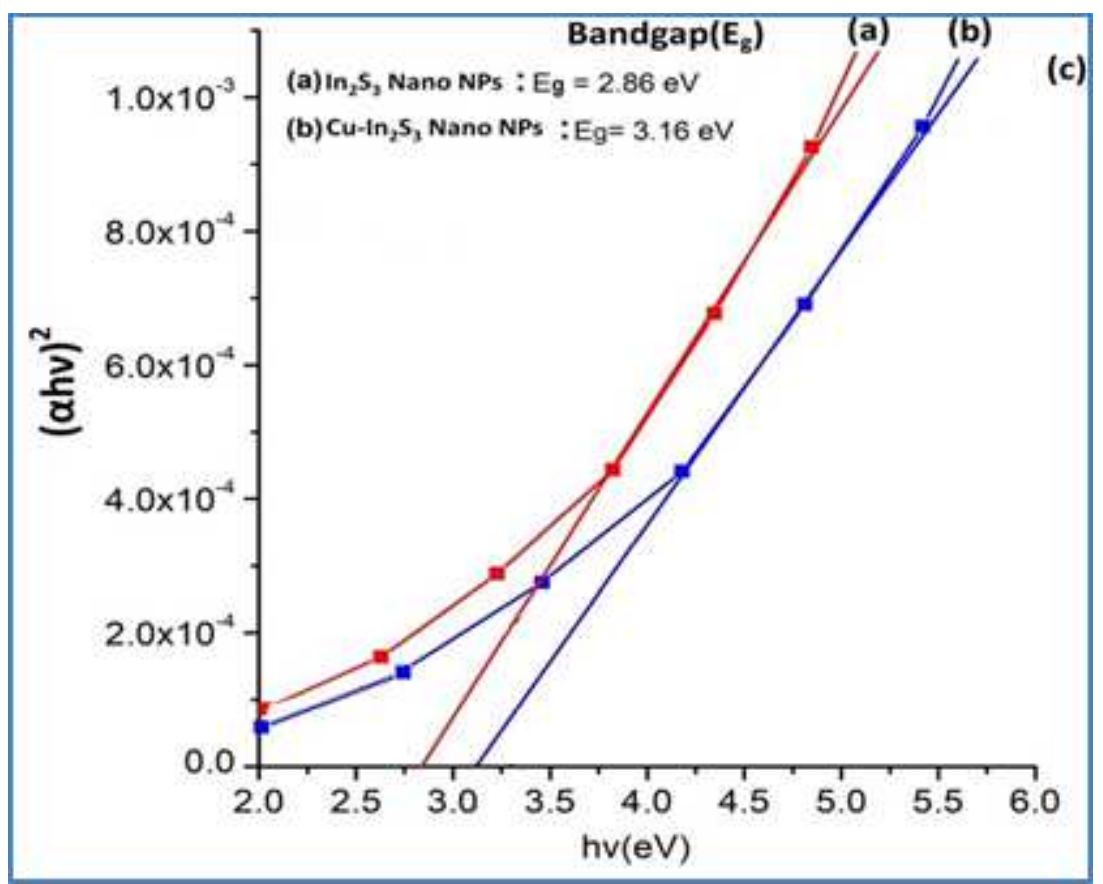

Figure 6

Optical bandgap energy $(\mathrm{Eg})$ of pure and metal $(\mathrm{Cu}, \mathrm{Mn})$ doped In2S3 NPs 


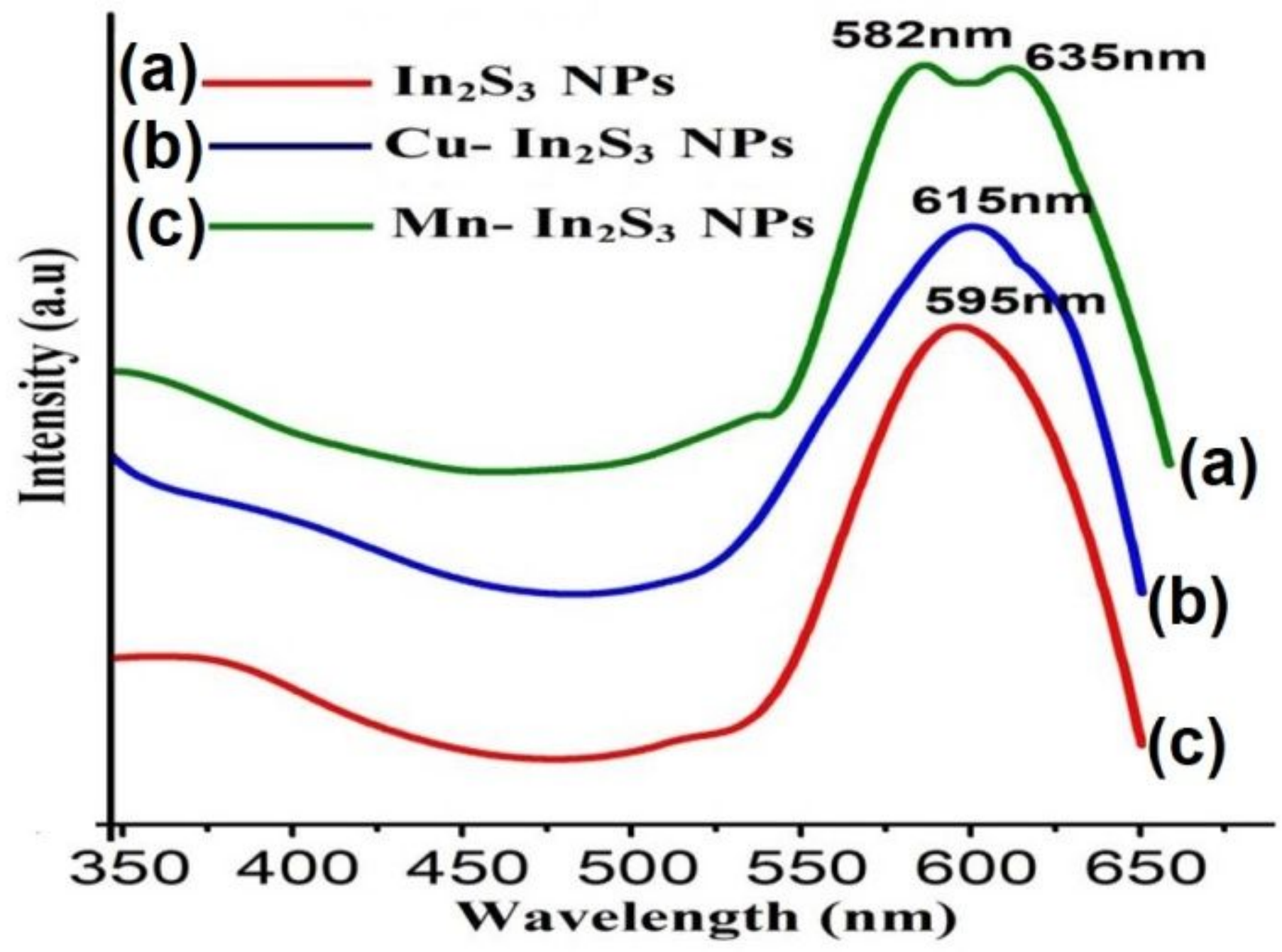

Figure 7

PL spectra of pure and metal (Cu, Mn) doped In2S3 NPs 

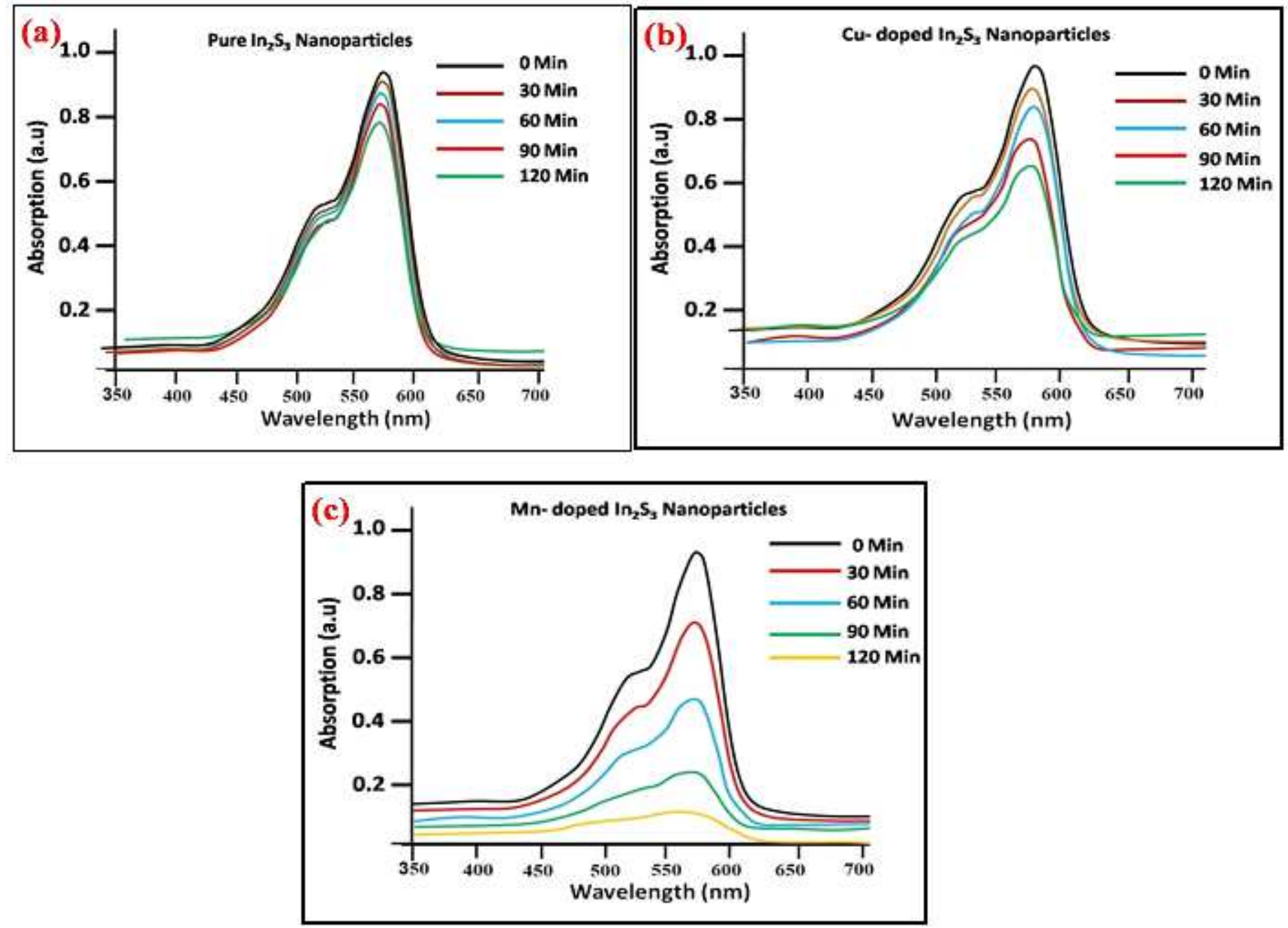

\section{Figure 8}

(a-c). The photocatalytic activity of pure and metal (Cu, Mn) doped In2S3 NPs with Methylene blue (MB) under different intervals of time (0-120 min). 


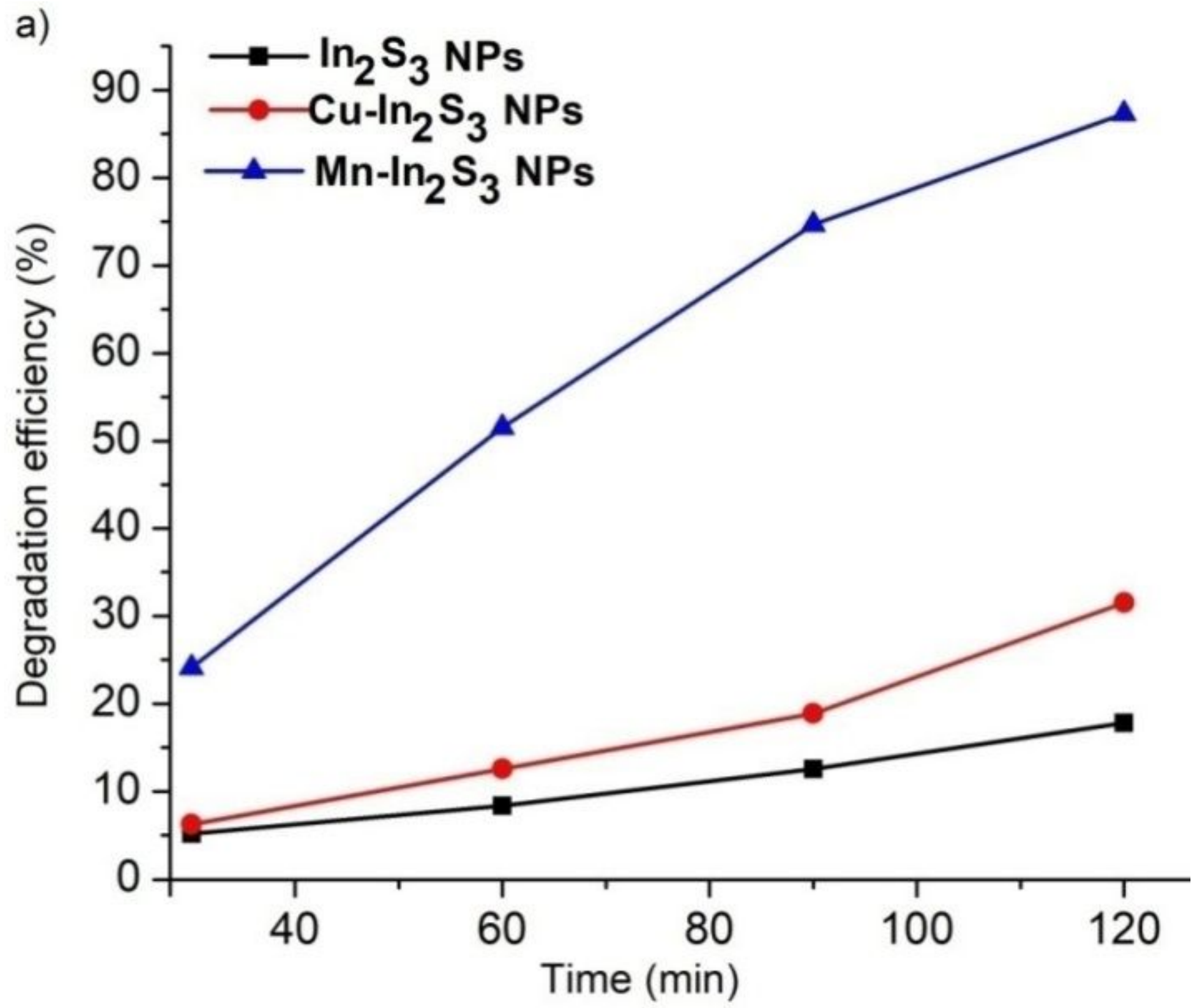

Figure 9

Kinetics of Methylene blue dye for pure and metal (Cu, Mn) doped In2S3 NPs under UV-Visible radiation. 


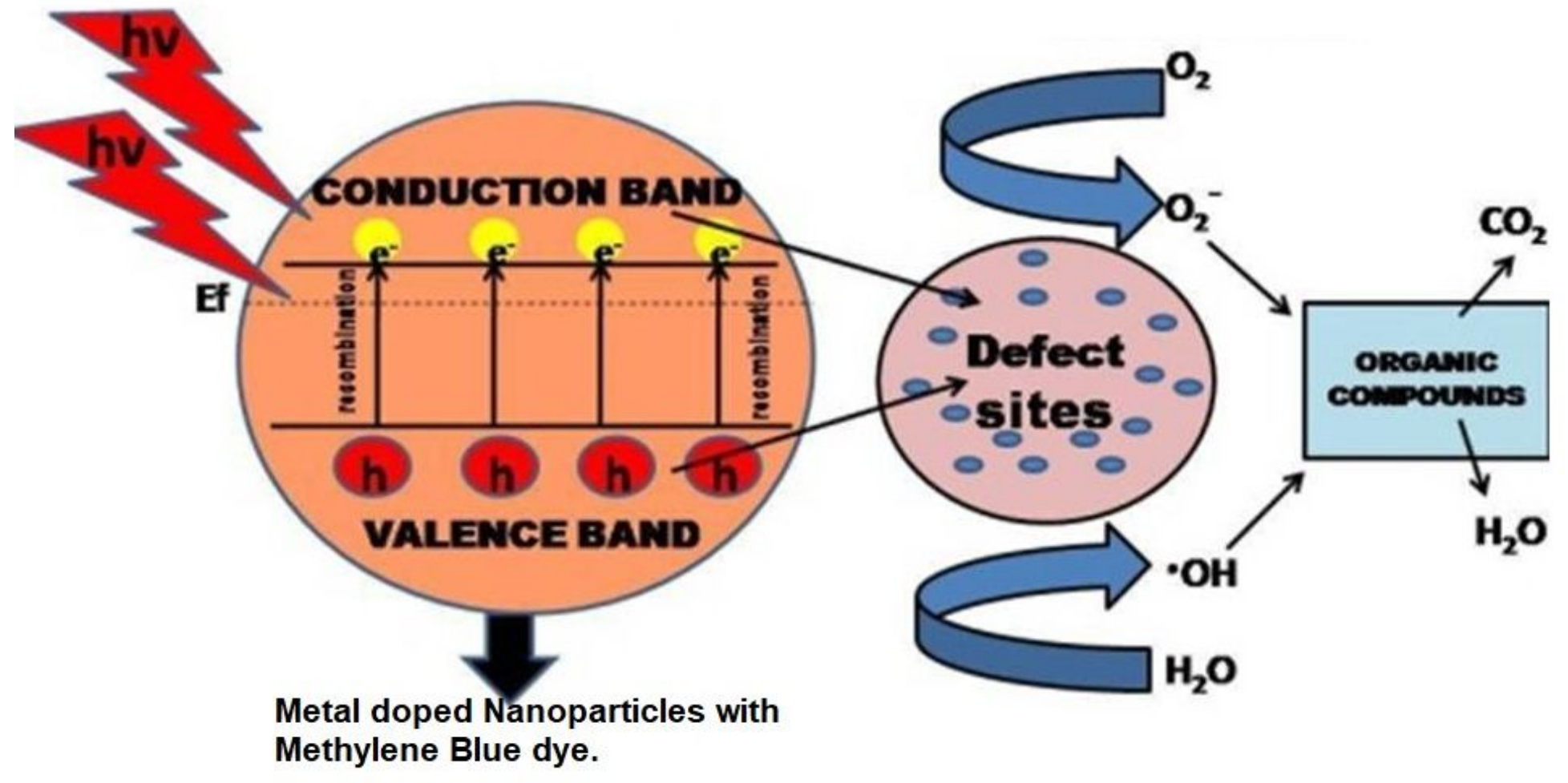

Figure 10

Photodegradation of Methylene blue in Visible light. 